\title{
The ECHR, THE HRA AND PROTeCting Human Rights IN THE UK: A VIEW FROM INTERNATIONAL LAW
}

\author{
Emma McClean
}

\section{Introduction}

With 2020 marking seventy years since the European Convention on Human Rights (ECHR) opened for ratification and twenty years from the commencement of the Human Rights Act (HRA), it is an opportune moment to reflect on the interplay between the ECHR and the HRA as human rights laws guaranteeing human rights in the UK. Such an exercise may also be apposite given the election manifesto pledge of the current UK government to 'update' the HRA, ${ }^{1}$ the development of a common law protection of rights by the domestic courts ${ }^{2}$ and, indeed, the continued recalcitrance of the UK to implement judgments of the European Court of Human Rights (ECtHR) on legacy issues arising from the Troubles in Northern Ireland. ${ }^{3}$ In combination, these perhaps harbinger an adjustment or recalibration of the legal protection of human rights in the UK - at least via the ECHR and/or the HRA. The academic literature is replete with assessments - to borrow a phrase - of the 'utility and futility' of the HRA ${ }^{4}$ with many diagnosing an ever expansive interpretation of human rights by the ECtHR as a source of the HRA's ills, ${ }^{5}$ along with the role played by the jurisprudence of the ECtHR in domestic

\footnotetext{
${ }^{1}$ The Conservative Election Manifesto 2019 available at https://www.conservatives.com/our-plan accessed 2312-20. A similar pledge was made in the 2017 Election Manifesto. See Helen Fenwick and Roger Masterman, 'The Conservative project to 'break the link between British courts and Strasbourg': Rhetoric or reality?' (2017) 80 (6) Modern Law Review 1111

${ }^{2}$ For a review of this development see, for example, Richard Clayton, 'The Empire Strikes Back: Common law rights and the Human Rights Act' (2015) Public Law 3, Roger Masterman and Steven Wheatle, 'A Common Law Resurgence in Rights Protection?' (2015) European Human Rights Law Review 57 and Conor Gearty, 'On Fantasy Island: British Politics, Judges and the European Convention on Human Rights' (2015) European Human Rights Law Review 1.

${ }^{3}$ Committee of Ministers, 'McKerr and seven other decisions against the United Kingdom' 13-12-20 Interim Resolution CM/ResDH (2020) 367.

${ }^{4}$ Keith D. Ewing, 'The Futility of the Human Rights Act' (2004) Public Law 829 and Lord Lester, 'The Utility of the Human Rights Act: A reply to Keith Ewing' (2005) Public Law 249. More generally, see Keith D. Ewing and Joo-Cheong Tham, 'The Continuing Futility of the Human Rights Act' (2008) Public Law 668, Aileen Kavanagh, 'Judging the Judges under the Human Rights Act: Deference, disillusionment and the 'war on terror' (2009) Public Law 287, Conor Gearty, 'The Human Rights Act: An academic sceptic changes his mind but not his heart' (2010) 6 European Human Rights Law Review 528 and Stephen Gardbaum, 'How Successful and Distinctive is the Human Rights Act?' (2011) 74 (2) Modern Law Review 195 and Merris Amos, 'Problems with the Human Rights Act and How to remedy Them: Is a Bill of Rights the answer?' (2009) 72 (6) Modern Law Review 883.

${ }^{5}$ For example, Baroness Hale, 'Beanstalk or Living Instrument? How tall can the European Convention on Human Rights grow? Gresham College Speech (16 June 2011) available at https://www.gresham.ac.uk/lectures-andevents/beanstalk-or-living-instrument-how-tall-can-the-european-convention-on-human accessed 28-12-20. From a European perspective see Alastair Mowbray, 'The Creativity of the European Court of Human Rights' (2005) 5 (1) Human Rights Law Review 57 and George Letsas, Theory of Interpretation of the European Convention on Human Rights (OUP 2007).
} 
judicial decision-making and the concomitant question of whether the UK Supreme Court or the ECtHR is the 'final arbiter' of human rights in the UK. ${ }^{6}$ While the thrust of this academic disquiet around the HRA is clear ${ }^{7}$ - namely, the interplay with the ECHR, specifically the ECtHR and its jurisprudence - few scholars approach this interplay from the vantage point of international law. ${ }^{8}$ As such, this reflection brings an international law perspective to bear on the interplay between the ECHR and the HRA as human rights laws guaranteeing human rights in the UK. Indeed, the reflection centres on the premise that the interplay between the ECHR and the HRA is one of a relationship between international law and domestic law, specifically the implementation of international law via domestic law. ${ }^{9}$

As human rights laws the ECHR and the HRA share a common anatomy; namely, the enumeration of human rights, the creation of obligations for states or public authorities, and the provision for remedies in the event of violation. ${ }^{10}$ This taxonomy is adopted as heuristic device to identify the points of interaction between the ECHR as an international treaty and the HRA as a domestic statute protecting human rights in the UK. The examination of the ECHR, undertaken in the first part of the paper, reveals a shifting stance to domestic law by the ECtHR, one premised on constructive dialogue. The second part of the paper assesses the HRA and exposes the unsettled approach of the domestic courts to the ECHR, specifically the jurisprudence of the ECtHR. As such, the third part of the paper considers, from the vantage point of international law, the possibility of a synergy between the approaches whereby the protection of human rights in the UK via the ECHR and the HRA may be enhanced.

\footnotetext{
${ }^{6}$ See generally, Brenda Hale, 'Argentoratum Locutim: Is Strasbourg or the Supreme Court supreme? (2012) 12 (1) Human Rights Law Review 65; for a third dimension to the issue in the aftermath of the judgment in In Re P [2008] UKHL 48 see Aileen Kavanagh, 'Strasbourg, the House of Lords or Elected Politicians: Who decides about rights?' after In re P (2009) 72 (5) Modern Law Review 828; and, finally, for the European perspective on the question see Nicholas Bratza, 'The Relationship between the UK Courts and Strasbourg' (2011) 5 European Human Rights Law Review 505 and Robert Spano, 'Universality or Diversity of Human Rights? Strasbourg in the age of subsidiarity’ (2014) Human Rights Law Review 487.

${ }^{7}$ The disquiet has been echoed by members of the UK judiciary, both in judgments and extra-judicially.

${ }^{8}$ There is an emerging literature from a European perspective on judicial interpretation: see Djeffal, 'Dynamic and Evolutive Interpretation of the ECHR by Domestic Courts? An inquiry into the Judicial Architecture of Europe' and Tzanakopoulous, Judicial Dialogue as a Means of Interpretation' both in Dinah Shelton, International Law and Domestic Legal Systems: Incorporation, Transformation and Persuasion (OUP 2011). While there has been a relative explosion of academic scholarship on the reception of the ECHR into the domestic legal systems of the states parties, the literature in international law as regards the implementation into domestic law, tends to skim over the Human Rights Act. It is this gap that this paper begins to address.

${ }^{9}$ On the relationship between international law and domestic law see, for example, Janne E. Nijmann and Andre Nolkaemper, New Perspectives on the Divide Between National and International Law (OUP 2007).

${ }^{10}$ This taxonomy was identified by Philip Alston as the characteristics of Bills of Rights, which was employed by Francesca Klug to argue that the HRA is a Bill of Rights. See Philip Alston, Protecting Human Rights through Bills of Rights (CUP 199) and Francesca Klug, 'A Bill of Rights: Do we need one or do we already have one?'. A similar taxonomy was identified by Theodor $\mathrm{C}$ van Boven in respect of UN human rights treaties.
} 


\section{The ECHR: Protecting Human Rights from Afar}

Having opened for ratification in 1950, the ECHR came into force in 1953 upon receipt of the necessary number of ratifications. ${ }^{11}$ States parties to the ECHR, including the UK as one of the original twelve signatories, ${ }^{12}$ undertake 'to secure to everyone within their jurisdiction' the rights listed in the ECHR ${ }^{13}$ and, where relevant, ${ }^{14}$ those enumerated in the Additional Protocols to the ECHR. ${ }^{15}$ Moreover, states parties to the ECHR accept the jurisdiction of the ECtHR, in particular as regards inter-state cases and individual applications as provided for in Article 33 and Article 34 of the ECHR respectively. ${ }^{16}$ While the protective reach of the ECHR and its Protocols - and thus the ECtHR - now extends to forty seven states (and to some 820 million people), the ECHR marked, in the words of the Preamble 'the first steps ${ }^{17}$ not only in translating the 'common standard' of the Universal Declaration of Human Rights (UDHR) ${ }^{18}$ into law; but also, 'for the collective enforcement of certain of the rights stated in the Universal Declaration', i.e the establishment of the ECtHR. ${ }^{19}$ In this latter respect, the ECHR remains unrivalled as regards the regional human rights treatie ${ }^{20}$ and without parallel in respect of the UN human rights treaties, such as the International Covenant on Civil and Political Rights

\footnotetext{
${ }^{11}$ As per the original ECHR (Article 66), ten ratifications were required for the ECHR to enter into force. As there were ten member states of the Council of Europe at the time (namely, Belgium, France, Luxembourg, the Netherlands, the UK, Ireland, Italy, Denmark, Norway and Sweden), this provision amounted to an injunction for all member states of the Council of Europe to be bound by the ECHR. Today, it is a requirement of membership of the Council of Europe to ratify the ECHR.

${ }^{12}$ The original or founding states are: Belgium, Denmark, France, Germany, Iceland, Ireland, Italy, Luxembourg, Netherlands, Norway, Turkey and the United Kingdom.

${ }^{13}$ ECHR Article 1

${ }^{14}$ For states to be bound to 'secure' the rights found in the Additional Protocols, they must also be party to the Additional Protocol

${ }^{15}$ These rights include the right to education, peaceful enjoyment of property and free elections by free ballot added by Additional Protocol 1 in 1952 while Additional Protocol 4 added, amongst others, the right to liberty of movement and freedom to choose one's residence in 1963 and, more recently, the 2002 Additional Protocol 13 prohibits the death penalty in all circumstances, including during war or threat of war. This Additional Protocol further strengthens the abolition of the death penalty found in Additional Protocol 6 of 1983. In this respect, Article 2 of the ECHR (the right to life) is modified as regards the exception in relation to the death penalty. See Mowbray, 'The Creativity of the European Court of Human Rights' $n$ at 67-8. Thus, Additional Protocols update human rights protection in terms of providing for new rights and developing existing ones. See Christine Chinkin 'Sources' in Moeckli et al International Human Rights Law (OUP 2010) 108 -109.

${ }^{16}$ Additional Protocol 11 (1994) amended the ECHR to provide for the compulsory jurisdiction of the ECtHR. Prior to this, states parties - in line with international law generally - specifically consented to the jurisdiction of the ECtHR which the UK did in 1969.

${ }^{17}$ ECHR Preamble

${ }^{18}$ UDHR Preamble

${ }^{19}$ ECHR Preamble

${ }^{20}$ The African Court for Human and People's Rights is provided for by a Protocol to the African Charter which, as was the original position under the ECHR and is the current position in respect of the jurisdiction of the InterAmerican Court of Human Rights, states parties must become party to in order to accept the jurisdiction of the African Court. The Court began operating in 2004 and, like the ECtHR, may receive allegations of violations from individuals. In contrast the Inter-American Court may only receive petitions from states (who have accepted its jurisdiction) or the Inter-American Commission. It began operating in 1979.
} 
(ICCPR). ${ }^{21}$ Before considering the role of the ECtHR, especially in respect of the protection of human rights in the UK, two points ought to be made regarding the legalisation of the human rights enunciated in the UDHR by the ECHR along with a further remark on the nature of the states parties' obligation under Article 1 of the ECHR.

In order to be a 'common standard of achievement for all peoples and all nations' the UDHR sets forth a 'common understanding' of human rights ${ }^{22}$ which, in the words of Charles Malik - a member of the 18-member strong UN Commission on Human Rights charged with drafting the $\mathrm{UDHR}^{23}$ - embodies 'man as he really was'; ${ }^{24}$ thereby running the gamut of thirty civil, cultural, economic, political and social rights. The ECHR and its Protocols guarantee civil and political rights only. That no socio-economic rights are enumerated is unsurprising as the majority of the original signatories to the ECHR - Belgium, Denmark, France, Germany (then the FRG), Greece, Iceland, Ireland, Italy, Luxembourg, the Netherlands, Norway, Sweden, Turkey and the UK - fell within the so-called 'Western' bloc of the polarised debate fomenting at the UN regarding the translation of the UDHR into legally binding commitments. The parameters of this debate were succinctly summarised in the contemporaneous UN record in the following terms:

\begin{abstract}
. . . civil and political rights were enforceable, or justiciable, or of an 'absolute' character, while economic, social and cultural rights were not or might not be; that the former were immediately applicable, while the latter were to be progressively implemented; and that, generally speaking, the former were rights of the individual 'against' the State, i.e. against unlawful and unjust action of the State, while the latter were rights which the State would have to take positive action to promote ... the nature of civil and political rights and that of economic, social and cultural rights, and the obligations of the State in respect thereof were different. ${ }^{25}$
\end{abstract}

\footnotetext{
${ }^{21}$ As Javid Rehman has remarked, 'The ECHR has the distinction of being the first and foremost of the human rights treaties with a procedurally developed judicial mechanism of accountability'. Rehman, International Human Rights Law (Longman 2010) 182. On the possibility of a world human rights court see Manfred Nowak, 'The Need for a World Court of Human Rights' (2007) 7 (1) Human Rights Law Review 251.

${ }^{22}$ UDHR Premable

${ }^{23}$ On the drafting of the UDHR see Mary Ann Glendon, A World Made New (Random House 2002) and Johannes Morsink, The Universal Declaration of Human Rights (University of Pennsylvania 200)

${ }^{24}$ Jack Mahoney, The Challenge of Human Rights: Origin, development and significance (Wiley-Blackwell 2006)

${ }^{25}$ UN SG, Draft International Covenants on Human Rights UN Doc A/2929 (1 July 1995) at para. 9
} 
Such views resulted in the bifurcation of the legal protection of human rights at the UN and at the Council of Europe, with separate treaties for civil and political rights (the ICCPR and the ECHR) and for socio-economic rights (the International Covenant on Economic, Social and Cultural Rights and the European Social Charter). While the UK is party to all four treaties, the ECtHR 'increasingly rules on cases concerning socio-economic rights'; ${ }^{26}$ most recently in the UK context in $J D$ and $A v U K$ concerning changes to the social benefits of the applicants. ${ }^{27}$ The expanding jurisprudence of the ECtHR, largely centred on interpretations of Articles 8 and 14 of the ECHR, indirectly protects socio-economic rights and prompted Lady Hale to observe '[t]he Convention began life as a code of individual civil and political rights, not a code of social and economic rights'. ${ }^{28}$

The second point to be made regarding the legalisation of the UDHR rights pertains to limitation clauses. The UDHR acknowledges that the human rights therein - whether civil and political or socio-economic - may be limited by law 'solely for the purpose of securing due recognition and respect for the rights and freedoms of others and of meeting the just requirements of morality, public order and the general welfare in a democratic society'. ${ }^{29}$ The ECHR and, indeed, the ICCPR, does not contain a similar general limitation clause; rather a number of specific civil and political rights may be limited or restricted in accordance with law if necessary, amongst others, to protect public order, health, or the fundamental rights and freedoms of others. ${ }^{30}$ Moreover, states parties to the ECHR and the ICCPR - such as the UK may temporarily suspend the obligation 'to secure' and 'to respect and to ensure' certain civil and political rights in 'times of public emergency'. ${ }^{31}$ Such permissible restrictions or, in the case of derogation, suspension invite different levels of human rights protection by state

\footnotetext{
${ }^{26}$ Ingrid Leijten, Core Socio-Economic Rights and the European Court of Human Rights (CUP 2017) 1

${ }^{27} J D$ and $A$ v UK (Application No 32949/17) Judgment 24 October 2019.

${ }^{28}$ Kay and another $v$ London Borough of Lambeth [2006] UKHL 10 [192] per Baroness Hale. See Merris Amos, The Second Division in Human Rights Adjudication: Social Rights Claims under the Human Rights Act (2015) Human Rights Law Review and Ellie Palmer, Judicial Review, Socio-Economic Rights and the Human Rights Act (OUP 2007)

${ }^{29}$ UDHR Article 29. Article 4 of the ICESCR contains a similar general limitation clause.

${ }^{30}$ See Articles 8-11 ECHR and Articles $17-22$ ICCPR. Other civil and political rights, such as the right to liberty and security of the person (Article 5, ECHR and Article 9, ICCPR) are qualified rights, i.e. they may be limited in carefully circumscribed circumstances and in accordance with law.

${ }^{31}$ Article 15 ECHR and Article 4 ICCPR. See Belmarsh Detainee case where the House of Lords considered both Article 15 ECHR and Article 4 ICCPR when assessing the derogation from Article 5, ECHR. A and others $v$ Secretary of State for the Home Department [2004] UKHL 56. Arguably the higher level of requirements for derogation found in Article 4 where in a factor in the decision. See Jonathan Black-Branch, The Derogation of Rights under the UK Human Rights Act: Diminishing international standards? (2001) 22 (1) Statute Law Review 71.
} 
parties $^{32}$ and arguably, as the civil and political rights of the ECHR are textually distinct from those of the ICCPR, ${ }^{33}$ variation in protection between human rights treaties; all of which is premised on the domestic law which operates to side-step the international law on human rights. In so doing, the international law on human rights appears to stand in stark contrast to the typical stance of international law to domestic law, whereby international law prevails over domestic law (especially when there is a conflict) - domestic law is not a defence for failure to fulfil an international legal obligation ${ }^{34}$ - and indeed, seems to fly in the face of pacta sunt servanda whereby obligations are performed in good faith. ${ }^{35}$

As regards the international legal obligation under the ECHR - the final remark before considering the role of the ECtHR - Article 1, as noted above, obliges states parties 'to secure to everyone within their jurisdiction' the civil and political rights enunciated therein and, where relevant, those listed in the Additional Protocols to the ECHR. This is comparable to the international legal obligation under Article 2 (1) of the ICCPR which enjoins states parties, including the UK, 'to respect and to ensure to all individuals within its territory and subject to its jurisdiction' the civil and political rights laid down in the ICCPR. Beyond prescribing an obligation of result, the ECHR and the ICCPR - as with international law in general $^{36}-$ are $^{2}$ largely silent on how states parties comply or fulfil their obligations 'to secure' the ECHR rights and 'to respect and to ensure' the ICCPR rights. Indeed, as Tomuschat observes, these obligations are little more than a reiteration of the general obligation on states to comply with international law, i.e. pacta sunt servanda. ${ }^{37}$ That said, the ECHR and the ICCPR stipulate that states parties are to comply with their Article 1 and Article 2(1) obligations without discrimination on the (non-exhaustive) grounds of 'race, colour, sex, language, religion,

\footnotetext{
${ }^{32}$ Douglas Lee Donoho, 'The Role of Human Rights in Global Security Issues' (1993) 14 Michigan Journal of International Law 827

${ }^{33}$ Schmidt warns of the fragmentation of the international law on human rights precisely because of the potential for variation in interpretation and application by state parties. In this respect he welcomes the use of UN treaty body jurisprudence by the regional human rights courts and domestic courts as favouring 'the emergence of substantively consistent and truly universal human rights jurisprudence'. Martin Schmidt, 'United Nations' in Moeckli et al n 15, 415.

${ }^{34}$ See Article 27 VCLT and Article 3 Draft Articles on International Wrongful Acts. As regards the position of international law in respect of domestic law 'it is certain that France cannot rely on her own legislation to limit the scope of her international obligations ...' Free Zones of Upper Savoy and the District of Gex (1932) PCIJ Ser A/B No 46, 167. Similarly a state 'cannot adduce as against another State its own Constitution with a view to evading obligations incumbent upon it under international law or treaties in force'. Treatment of Polish Nationals in the Danzig Territory (1932) Ser A/B No 44, 24.

${ }^{35}$ This is a principle of customary international law and is found in Article 26 VCLT.

${ }^{36}$ Indeed most of international law may be said not to require instruction as to how to implement the legal obligation; a case in point here is the prohibition on the threat or use of force. However, the principle of the sovereign equality of states dictates that it is for states to determine whether and, if so, how international law is implemented.

${ }^{37}$ Christian Tomuschat, Human Rights (2 ${ }^{\text {nd }}$ ed OUP 2007) 124.
} 
political or other opinion, national or social origin, property, birth or other social status ${ }^{38}$ with the ECHR adding 'association with a national minority'. ${ }^{39}$ The ICCPR further obligates states parties 'to take steps . . . to adopt such laws or other measures as may be necessary to give effect to the rights recognised in the present Covenant'. ${ }^{40}$ The Human Rights Committee (HRC), the body charged under the ICCPR with monitoring compliance, ${ }^{41}$ has stated that Article 2 (2) of the ICCPR requires:

... States Parties ... on ratification to make such changes to domestic laws and practices as are necessary to ensure their conformity with the Covenant. Where there are inconsistencies between domestic law and the Covenant, article 2 requires that the domestic law or practice be changed to meet the standards imposed by the Covenant's substantive guarantees. Article 2 allows a State Party to pursue this in accordance with its own domestic constitutional structure and accordingly does not require that the Covenant be directly applicable in the courts, by incorporation of the Covenant into national law. ${ }^{42}$

This is a reflection of the general obligation in international law for states to ensure that domestic law conforms to international law ${ }^{43}$ while 'taking steps' within 'its own domestic constitutional structure' is a nod to the foundational international law principle, that of the sovereign equality of all states. ${ }^{44}$ Thus, states decide whether (or not) to make international law part of domestic law and, upon doing so, determine the place or status of international law within the domestic legal system. Moreover, in a further concession to the principle of sovereign equality, the absence of a domestic law (or even failure to change domestic law) may not necessarily breach the obligation to bring domestic law into line with international law. Indeed, ECtHR rejected an argument by Ireland that the UK breached Article 1 of the ECHR

\footnotetext{
${ }^{38}$ Article 2 (1) ICCPR Article 2 (1).

${ }^{39}$ Article 14 ECHR Article 14.

40 ICCPR Article 2 (2). See Human Rights Committee, General Comment No. 31 (26 May 2004) CCPR/C/21/Rev.1/Add. 1326 May 2004 [13 - 14].

${ }^{41}$ ICCPR Article 28 (establishment of the Committee) and ICCPR Articles 40 - 43 (functions of the Committee)

${ }^{42}$ Human Rights Committee, General Comment No 31 n [13]. The original General Comment on the obligation 'to respect and to ensure' reflected the general position of international law: 'article 2 of the Covenant generally leaves it to the States parties concerned to choose their method of implementation in their territories'

${ }^{43}$ Exchange of Greek and Turkish Populations (1925) PCIJ Ser B No 10, 20.

${ }^{44}$ UN Charter Article 2 (1). The International Court of Justice has repeatedly affirmed the fundamental nature of the principle of sovereign equality of all states. For example, in the Nicaragua (Merits) Case the Court stated that 'State sovereignty' is a fundamental principle 'on which the whole of international law rests' and which entails 'the freedom of choice of the political, social, economic, and cultural system of a State'. Nicaragua (Merits) [263].
} 
due to the absence of a domestic law prohibiting torture (Article 3 of the ECHR) with the ECtHR observing:

Article 1 (art. 1) is drafted by reference to the provisions contained in Section I [the ECHR rights] and thus comes into operation only when taken in conjunction with them; a violation of Article 1 (art. 1) follows automatically from, but adds nothing to, a breach of those provisions; hitherto, when the Court has found such a breach, it has never held that Article 1 (art. 1) has been violated..$^{45}$

Before continuing to note:

The absence of a law expressly prohibiting this or that violation does not suffice to establish a breach since such a prohibition does not represent the sole method of securing the enjoyment of the rights and freedoms guaranteed. ${ }^{46}$

Here, the ECtHR determined that the relevant domestic law and practices breached Article 3 of the ECHR and thus the UK had violated Article 3. Thus, as with international law generally, a breach of the obligation to ensure that domestic law conforms to international law 'arises only when the state concerned fails to observe its obligations on a specific occasion'; ${ }^{47}$ which, as was the case in Ireland $v U K$, may be evidenced by domestic laws and practices. ${ }^{48}$ In this light, it is unsurprising that both the ECtHR and the Human Rights Committee do not view Article 1 of the ECHR or Article 2 of the ICCPR as requiring the ECHR or the ICCPR to be brought into domestic law, either by way of 'direct incorporation or through transformative legislation'. ${ }^{49}$ That said, the ECtHR, like the HRC, has noted that the obligation 'finds a particularly faithful reflection in those instances where the Convention has been incorporated into domestic law' ${ }^{50}$

In sum, by mapping onto the general obligation in international law to ensure conformity between domestic law and international law (which flows from pacta sunt servanda), Article

\footnotetext{
45 Ireland v UK (Application No 5310/71) Judgment 18 January 1978 [238].

${ }^{46}$ Ibid [240].

47 James Crawford, Brownlie's Principles of International Law (9 $9^{\text {th }}$ ed OUP 2019) 49.

${ }^{48}$ For the approach of the ICJ in this regard, see Belgium $v$ Senegal (2012) ICJ Rep 422, 451-2.

${ }^{49}$ Shelton $\mathrm{n} 2$.

${ }^{50}$ Ireland $v U K \mathrm{n}$. [239]. The HRC has remarked that 'The Committee takes the view, however, that Covenant guarantees may receive enhanced protection in those States where the Covenant is automatically or through specific incorporation part of the domestic legal order'. HRC, General Comment No. $31 \mathrm{n}$ [13].
} 
1 of the ECHR and Article 2 of the ICCPR afford states parties considerable discretion as to how to implement their obligations 'to secure' the ECHR rights and 'to respect and to ensure' the ICCPR rights to individuals within their jurisdiction, including whether or not to bring the civil and political rights therein into domestic law. Such discretion appears tempered by the obligation on states parties to provide an effective domestic remedy which, although is not required to be judicial in nature, must be capable of determining an allegation of a violation of the ECHR rights or ICCPR rights and, where appropriate, to provide redress; ${ }^{51}$ prompting 'the question ... as to whether the insistence on remedies permitting the individual to defend his/her rights does not presuppose that those rights must be present within every domestic legal order of states parties'. ${ }^{52}$

\section{The Role of the European Court of Human Rights}

As a human rights law, the ECHR enumerates civil and political rights, creates obligations for states parties, including the obligation to provide an effective domestic remedy and provides for a system of 'collective enforcement' by establishing the ECtHR. ${ }^{53}$ In other words, the ECHR, as with human rights treaties generally, creates 'rights for individuals and duties for states, as well as domestic and international remedies for violation of rights and failure of duties'.54 As an international treaty, the ECHR and indeed, the ICCPR, the International Covenant on Economic, Social and Cultural Rights and the European Social Charter, adopts the 'form' of international law for human rights protection. In doing so, the logic of the principle of sovereign equality is pitted against the imperative of human rights protection. ${ }^{55}$ Thus, the discretion engendered by the principle in the implementation of the obligation 'to secure' the ECHR rights (as noted above) augurs a dualist stance to the relationship between international law and domestic law - at least from the perspective of international law - whereby international law may not prevail over domestic law. ${ }^{56}$ Yet, as pacta sunt servanda entails the

\footnotetext{
${ }^{51}$ See Silver v UK (Application No 5947/72) Judgment 25 March 1983 [113]; Human Rights Committee, General Comment No $31 \mathrm{n}$ [15-16].

52 Tomuschat $\mathrm{n}$ 115. The ECtHR has answered this question in the negative, holding in Smith and Grady $v$ UK that Article 13 'does not go so far as to require incorporation of the Convention or a particular form of remedy, Contracting States being afforded a margin of appreciation in conforming with their obligations under this provision'. Smith and Grady v UK (Application No 33985/96) Judgment 27 September 1999 [135]

53 The Preamble speaks of 'collective enforcement for certain of the rights in the Universal Declaration' while Article 19 details the observance of obligations by the ECtHR.

${ }^{54}$ Saladin Meckled-Gracía and Başak Çali, 'Lost in Translation’ in Saladin Meckled-Gracía and Başak Çali (eds) The Legalisation of Human Rights: Multidisciplinary perspectives on human rights and human rights law (Routledge 2009), 14

${ }^{55}$ Frederic Mègret, 'Nature of Obligations' in Moeckli et al n Chp 6. The imprint of sovereignty is also evident in the treaty provisions themselves, specifically the limitation clauses.

56 Shelton $n$
} 
superiority of international law ${ }^{57}$ attention is drawn to "modes of enforcement' ${ }^{58}$ or methods of ensuring compliance with human rights obligations ${ }^{59}$ that are outside the purview of the traditional means of enforcing or ensuring compliance with international law - which are either unavailable or inappropriate ${ }^{60}$ - and do not rely on states parties. It is against this background, that this section explores - somewhat cursorily - the role of the ECtHR as the lodestar of the innovative and largely unique measures provided for by human rights treaties to monitor compliance and enforce human rights obligations. As ever, the focus is on the UK domestic context, as the section seeks to determine the parameters of the effect of the ECHR on the domestic protection of human rights.

The primary function of the ECtHR is to adjudicate on claims brought a state party to the ECHR in respect of a 'breach of the provisions of the Convention and the Protocols thereto' by another state party (an inter-state case) and those brought by an individual 'claiming to be a victim of a violation ... of the rights set forth in the Convention or the Protocols thereto' by a state party to the ECHR (an individual application). ${ }^{61}$ While certainly not a major contributor to the caseload of the ECtHR, the UK has been party to both inter-state cases and individual applications; notably, in respect of the former, when Ireland alleged, amongst others, a violation of Article 3 of the ECHR by the UK. ${ }^{62}$ As regards the latter, the judgments of the ECtHR - which, as a matter of international law, are binding on the $\mathrm{UK}^{63}$ - have prompted changes in domestic laws, policies and practices; thereby ensuring conformity with international law. Yet, the intransigence of the UK in implementing judgments in respect of prisoner voting rights and, as noted above, legacy issues arising from the Troubles in Northern Ireland, underscores the ECtHR's subsidiary role as an international court in the protection of human rights; serving as a reminder that 'the primary responsibility to secure' the ECHR rights lies with states parties which, moreover, 'enjoy a margin of appreciation' in the implementation of their Article 1 obligation, albeit, 'subject to the supervisory jurisdiction' of the ECtHR. ${ }^{64}$

\footnotetext{
57 VCLT Article 27.

58 Megret $n$

${ }^{59}$ As observed by Tomuschat 'the maxim pacta sunt servanda ... raises problems of a complexity hitherto unheard of. The need to secure the pre-eminence of the CCPR over any kind of conflicting normative rules requires an elaborate system of remedies'. Tomuschat n 121

${ }^{60}$ Megret n 146-7.

${ }^{61}$ ECHR Article 33 and Article 34 respectively.

${ }^{62}$ Ireland $v U K \mathrm{n}$

${ }^{63}$ ECHR Article 46

${ }^{64}$ Additional Protocol No. 15 Article 1. Although not yet in force, the inclusion of this provision in the Preamble of the ECHR is understood to merely reflect the existing jurisprudence of the ECtHR - see Robert Spano, 'Universality or Diversity of Human Rights? Strasbourg in the Age of Subsidiarity' (2014) 14 Human Rights Law Review 487, 491. The subsidiary role of the ECtHR is reinforced by the requirement that domestic remedies are
} 
The margin of appreciation, first developed in the context of derogation (Article 15 of the ECHR) and subsequently deployed by the ECtHR in respect of the ECHR rights with limitation clauses, affords states parties discretion when suspending or limiting the enjoyment of the ECHR rights; and thus may be seen as a concession to the principle of sovereign equality, above and beyond that entailed by the limitation clauses themselves. ${ }^{65}$ This stands in contrast to the position adopted by the HRC - the treaty body of the ICCPR - which, when examining individual communications, does not employ a margin of appreciation. ${ }^{66}$ Rather, the HRC, sees the limitation clauses, with their emphasis on domestic law, as building in discretion for states parties to the ICCPR in the implementation of their obligation 'to respect and to ensure' the ICCPR rights. ${ }^{67}$ Thus, for the HRC, its role as an international human rights body, is to assess 'whether, in a given situation, there may have been circumstances which made a restriction ... [of an ICCPR right] ... necessary'; ${ }^{68}$ and not, as per the ECtHR, for states parties to the ECHR which due to "their direct and continuous contact with the vital forces of their countries ... are in principle in a better position than the international judge to give an opinion on the exact content of these requirements as well as on the 'necessity' of a 'restriction' or 'penalty' intended to meet them'. ${ }^{69}$

Arguably the position of the HRC is more in line with the general approach of international law to domestic law whereby, as noted above, the merits (or otherwise) of a domestic law is largely irrelevant to the question of whether the application of such a law conforms to international law. However, as Meckled-Gracía and Çali observe, the existence of limitation clauses places 'bodies entrusted with adjudication of human rights law' ${ }^{70}$ - such as the HRC and the ECtHR - in the position of balancing the competing and perhaps incommensurate imperatives of sovereign equality with human rights protection. ${ }^{71}$ While the HRC, in refusing

\footnotetext{
exhausted and is reflected in the criteria for striking out an application. On the principle of subsidiarity in international human rights law see Paola Carozza, 'Subsidiarity as a Structural Principle of International Human Rights Law' (2003) 97 (1) American Journal of International Law 38 and in respect of the ECHR see Alastair Mowbray, 'Subsidiarity and the European Convention on Human Rights' (2015) 15 (2) Human Rights Law Review 315.

${ }^{65}$ On the margin of appreciation see and on the interplay with the principle of subsidiarity see Samantha Beson,

${ }^{66}$ See Sarah Joseph et al (eds), The ICCPR: Cases, Materials and Commentary (3 ${ }^{\text {rd }}$ ed OUP 2016) and Dominic McGoldrick, 'In Defence of the Margin of Appreciation and an Argument for its Application by the Human Rights Committee' (2016) 65 (1) International and Comparative Law Quarterly 21.

${ }^{67}$ See for example in respect of Article 19 see Sohn v Republic of Korea (Communication No. 518/1992) View DATE.

${ }^{68}$ HRC, General Comment No. 34, ‘Article 19: Freedoms of Opinion and Expression’ [16].

${ }^{69}$ Handyside v UK (Application No 5493/72) Judgment 7 December 1976 [48].

${ }^{70}$ Meckled-Gracía and Çali n 22.

${ }^{71}$ On this point see Başak Çali, 'Balancing Human Rights? Methodological Problems with Weights, Scales and Proportions' (2007) 29 (1) Human Rights Quarterly 251.
} 
to employ a margin of appreciation, may balance such imperatives with the possibility of international law prevailing over domestic law; the ECtHR, when applying the margin of appreciation, declines to do so (and so declines to exercise its adjudicatory function) with the result that domestic law prevails over international law. These approaches may produce variable outcomes in human rights protection between human rights treaties whereby, for example, a state party to both the ICCPR and the ECHR may be found to have violated the former and to have acted within its margin of appreciation as regards the latter. ${ }^{72}$ Moreover, the application of the margin of appreciation by the ECtHR may produce different outcomes for different states parties to the ECHR. Thus, when France was found to have violated the ECHR rights of the transgender applicant in $B v$ France,${ }^{73}$ the applicants in Sheffield and Horsham $v$ UK sought to displace the UK's margin of appreciation bestowed by the ECtHR in previous cases alleging the denial of ECHR rights (notably the right to respect for family and private life and the right to marry) to transgender persons. ${ }^{74}$ Here, the ECtHR noted that France had made some provision for the legal recognition of transgender persons which, along with the prevailing absence of a European consensus on the issue, meant that the UK continued to have the benefit of the margin of appreciation. That said, the ECtHR reiterated its injunction to the UK to keep the situation under review ${ }^{75}$ and ultimately, in Goodwin v UK, found 'good reason ${ }^{76}$ to depart from its previous position - namely, the presence of the previously elusive European consensus - whereby the UK 'can no longer claim that the matter falls within their margin of appreciation" 77 and, thus the ECtHR exercised its adjudicatory function, finding violations of the Article 8 rights (right to respect for family and private life) and Article 12 rights (right to marry) of the applicant by the UK. The UK implemented the judgment by enacting the Gender Recognition Act 2004, thereby bringing domestic law into line with its international legal obligations under the ECHR.

While the margin of appreciation, as a concession to the principle of sovereign equality, may produce variable outcomes in human rights protection between states parties to the ECHR and

\footnotetext{
${ }^{72}$ As was the case with France's burqa ban where the ECtHR found that the ban fell within the margin of appreciation, while the HRC found the ban violated freedom of religion. See SAS v France (Application No 43835/11) Judgment (Grand Chamber) 1 July 2014; Hebbedi v France (Communication No. 2807/2016) View 17 October 2018; and, Yaker v France (Communication No. 2747/2016) View 7 December 2018.

${ }^{73}$ B v France (Application No. 13343/87) Judgment 25 March 1992.

${ }^{74}$ Sheffield and Horsham v UK (Application No. 31-32/1997/815-816/1018-1019) Judgment 30 July 1998. The previous cases were Rees v UK (Application No. 9532/81) Judgment 17 October 1986 and Cossey v UK (Application No. 10843/84) Judgment 27 September 1990.

${ }^{75}$ Sheffield and Horsham $v$ UK, [60].

${ }^{76}$ Goodwin v UK (Application No. 28957/95) Judgment 11 July 2002 [74]

${ }^{77}$ Ibid [93].
} 
indeed, between the ECHR and the ICCPR as human rights treaties, it does not affect the interpretative function of the ECtHR. ${ }^{78}$ Indeed, when hearing cases and applications under Articles 33 and 34 of the ECHR, the jurisdiction of the ECtHR extends to the 'interpretation and application' of the ECHR and its Protocols ${ }^{79}$ and thus:

The Court's judgments in fact serve not only to decide those cases brought before the Court but, more generally, to elucidate, safeguard and develop the rules instituted by the Convention, thereby contributing to the observance by the States of the engagements undertaken by them as Contracting Parties ${ }^{80}$

As the ECHR is an international treaty, the ECtHR has adopted the rules on treaty interpretation as codified in the Vienna Convention on the Law of Treaties 1969 (VCLT), ${ }^{81}$ specifically Article 33 (1) which stipulates that '[a] treaty shall be interpreted in good faith in accordance with the ordinary meaning to be given to the terms of the treaty in their context and in the light of its object and purpose'. Moreover, as has been well-documented, the ECtHR has developed a teleological interpretative method whereby the 'object and purpose' of the ECHR as 'first and foremost a system for the protection of human rights ${ }^{\prime 2}$ is emphasised. This approach has given rise to two guiding interpretative principles; namely, rights as 'practical and effective" 83 and interpretation in 'light of present-day conditions' - the so-called 'living instrument' doctrine. ${ }^{84}$ Both of these principles were evident in the Goodwin v UK judgment when the ECtHR extended the protective reach of the relevant ECHR rights to the transgender applicant. ${ }^{85}$ Thus, while the UK was bound to implement the judgment and ensure the

\footnotetext{
${ }^{78}$ Sunday Times (No. 2) v UK (Application No.13166/87) Judgment 26 November 1991 were the ECtHR discussed the content, scope and application of Article 10 of the ECHR, before considering whether the UK enjoyed a margin of appreciation. In a domestic context, note the observation by Lord Bingham that 'Where [the ECtHR] concludes that there was no breach of a convention rights, the ECtHR may nevertheless rule on the reach of the right'. Secretary of State for the Home Department, ex parte Ullah [2004] UKHL 26 [35]. On the dual functions of the ECtHR and their impact on the functioning of the ECtHR, see Fiona de Londras, 'Dual Functionality and the Persistent Frailty of the European Court of Human Rights' (2013) 1 European Human Rights Law Review 38. ${ }^{79}$ ECHR Article 32.

${ }^{80}$ Ireland v UK n [154]. See also Jeronovics v Latvia (Application No 4488/10) Judgment 5 July 2016 [109] where the ECtHR reiterated the statement in Ireland $v U K$ and continued 'Although the primary purpose of the Convention system is to provide individual relief, its mission is also to determine issues on public-policy grounds in the common interest, thereby raising the general standards of protection of human rights and extending human rights jurisprudence throughout the community of the Convention states'.

${ }^{81}$ Golder v UK (Application No 4451/70) Judgment 21 February 1975.

${ }^{82}$ Goodwin v UK n [74]. See also the Belgian Linguistics Case where the ECtHR stated: 'the general aim set for themselves by the Contracting Parties through the medium of the European Convention on Human Rights, was to provide effective protection of fundamental human rights'. The Case Concerning [ I.B.5]

${ }^{83}$ Marrkx v Belgium (Application No ) Judgment Airey v Ireland (Application No ) Judgment

${ }^{84}$ Tyrer $v$ UK (Application No ) Judgment at para.

${ }^{85}$ Goodwin v UK n [74 - 75].
} 
conformity of domestic law with the ECHR, all states parties to the ECHR were put on notice of the development in the content, scope and application of the pertinent ECHR rights.

More generally, it is unsurprising that the principle that ECHR rights are to be 'practical and effective' as opposed to 'theoretical or illusory' 86 made an early appearance in the jurisprudence of the ECtHR, given the purpose of the ECHR 'to provide effective protection of human rights', ${ }^{87}$ especially as against arbitrary interference by states parties. ${ }^{88}$ The application of the principle has not only resulted in the expansion of the protective reach of the ECHR rights to, amongst others, transgender persons and unmarried mothers; ${ }^{89}$ but also, perhaps more significantly, has prompted the development of positive obligations for states parties. As noted above, the standard view when the ECHR was being drafted was that the ECHR rights, as civil and political rights, were of immediate application requiring states to merely refrain from certain conduct in order to fulfil their international obligations. Seen in this light, it is perhaps not surprising that the development of positive obligations by the ECtHR has been met with some resistance by states parties. ${ }^{90}$ For example, the UK railed against the Article 3 positive obligation whereby an individual may not be deported or extradited where there are 'substantial grounds for believing that the individual faces a real risk of' treatment contrary to Article 3 of the ECHR, namely torture, inhuman or degrading treatment or punishment; ${ }^{91}$ arguing before the ECtHR in Chahal that the positive obligation must be limited or balanced against the imperative of national security. ${ }^{92}$ That the ECtHR roundly rejected such arguments, did not prevent the UK from reiterating them as a third party intervener in subsequent individual applications ${ }^{93}$ or from re-purposing them in respect of the development of a similar positive obligation under Article 6 of the ECHR. ${ }^{94}$ In this latter respect, Lord Bingham's conclusion to his tour d'horizon of the jurisprudence of the ECtHR - undertaken in ex parte Ullah (discussed below) - that yes, 'in principle articles other than article 3 could become engaged in immigration decisions on the expulsion of aliens, ${ }^{95}$ may have been

\footnotetext{
${ }^{86}$ Airey v Ireland (Application No ) Judgment [24]

87 'Thus, the object and purpose of the Convention as an instrument for the protection of individual human beings require that its provisions be interpreted and applied so as to make its safeguards practical and effective'. Soering v UK (Application No.14038/88) Judgment 7 July 1989 [91]

${ }^{88}$ Belgian Linguistic Case $n$ [.

${ }^{89}$ Marrkz v Belgium (Application No ) Judgment

${ }^{90}$ See Alastair Mowbray, 'The Development of Positive Obligations'

91 Soering v UK (Application No.14038/88) Judgment 7 July 1989 [91] and Chahal v UK (Application No.22414/93) Judgment (Grand Chamber) 15 November 1996 [74].

${ }^{92}$ Chahal [76]

${ }^{93}$ See for example, Saadi v Italy (Application No. 377201/06) Judgment (Grand Chamber) 28 February 2008.

94 Othman (Abu Qatada) v UK (Application No.8139/09) Judgment 17 January 2012.

${ }^{95}$ Special Adjudicator ex parte Ullah n [40 - 50].
} 
instructive. It is a comparable positive obligation under Article 2 of the ECHR to investigate killings that has irked the UK in respect of the legacy issues arising from the Troubles in Northern Ireland.$^{96}$

While the living instrument doctrine made a later appearance in the jurisprudence of the ECtHR, ${ }^{97}$ it has had a profound impact on the content, scope and application of the ECHR rights. ${ }^{98}$ Indeed, interpretation of the ECHR rights 'in light of present-day conditions' is arguably the primary way in which the ECtHR updates and develops the ECHR. When doing so, the ECtHR is mindful of its subsidiary role as an international court, albeit for the 'effective protection of human rights'; premising any evolution in the content, scope and application of an ECHR right on developments within the state party concerned ${ }^{99}$ and, more generally, as amongst states parties to the ECHR 'as to the standards to be achieved' ${ }^{100}$ in human rights protection. Thus the common approach or European consensus that was evident in Goodwin, arguably provided the impetus for the development of the content, scope and application of Article 3 of the Additional Protocol No. 1 from an institutional right to hold elections, to universal suffrage, to subjective rights of participation, including the right to vote; ${ }^{101}$ while, the ECtHR was of the view that 'the increasingly high standard being required in the area of the protection of human rights and fundamental liberties correspondingly and inevitably requires greater firmness in assessing breaches of the fundamental values of democratic societies' required a lowering of the threshold of what constitutes torture for the purposes of Article 3 of the ECHR. ${ }^{102}$ In this way, the ECtHR may be said to be taking account of the context of the ECHR as per Article 31 (1)(b) of the VCLT which speaks of subsequent state practice as an aid to establishing 'the agreement of the parties regarding its interpretation'; and, in so doing,

\footnotetext{
${ }^{96}$ McKerr v UK (Application No. 28883/95) Judgment 4 May 2001. The House of Lords similarly found a positive obligation in respect of Article 2; however, the HRA did not have retrospective effect. See In Re McKerr [2004] UKHL 12. Subsequently, the Supreme Court has held that there is an obligation to investigate deaths arising from the Troubles in Northern Ireland.

${ }^{97}$ Tyrer $v$ UK n [31]. On the various interpretative phases of the ECtHR see Ed Bates, The Evolution of the European Convention on Human Rights: From its Inception to the Creation of a Permanent Court of Human Rights (OUP 2010) and on the interpretation of the ECHR more generally see Letsas n.

${ }^{98}$ Mowbray lists the following judgments as examples of this impact: Tyrer $v U K$ (prohibition of judicial corporal punishment), Stafford $v$ UK (limiting the role of government in determining release), Sigurjonsson v Iceland (right not to be compelled to belong to a trade union) and Goodwin $v U K$ (legal recognition of the new identify of a postoperative transsexual. See Mowbray n 69.

${ }^{99}$ See Stafford $v$ UK (Application No ) Judgment

${ }^{100}$ Tyrer v UK n Goodwin v UK n

${ }^{101}$ Mathieu-Mohin and Clerfayt v Belgium (Application No. 9267/81) Judgment 2 March 1987 [51].

${ }^{102}$ Selmouni v France (Application No. 25803/94) Judgment 28 July 1999 [101]
} 
developments at the domestic level - whether within a state party or amongst the states parties - 'influence Strasbourg to change its case-law'. ${ }^{103}$

The participation of states parties to the ECHR, via subsequent practice, in the interpretation of the ECHR rights by the ECtHR, stands in contrast to the explicit invitation extended to the ECtHR by the UK Supreme Court in $R v$ Horncastle to:
reconsider the particular aspect of the decision that is in issue [admissibility of untested hearsay evidence], so that there takes place what may prove to be a valuable dialogue between this court and the Strasbourg Court. ${ }^{104}$

The ECtHR accepted the invitation and modified its position on the relevant domestic law as affording sufficient protection of the ECHR right to a fair trial. ${ }^{105}$ In a comparable way the ECtHR and the UK House of Lords engaged in a dialogue as to the effectiveness of domestic law to secure Article 8 rights, specifically in respect of 'the home'. ${ }^{106}$ At issue here, in contrast to Horncastle, was not the conformity of domestic legislative provisions; but rather the effectiveness of the methodological tools employed by the court in determining whether Article 8 had been infringed. Here, against the backdrop of an increasing number of dissents within the House of Lords, the ECtHR prevailed and the House of Lords modified its approach, thereby bringing international law into domestic judicial decision-making. ${ }^{107}$ Granted a similar dialogue, albeit implied, ${ }^{108}$ occurs when cases are brought to the ECtHR following determination by the domestic courts - a case in point in the UK context may be the Animal Defenders Case $^{109}$ or the Belmarsh Detainees Case ${ }^{110}$. These along with the above referenced

\footnotetext{
103 Luzius Wildhaber, Speech on the Opening of the Judicial Year (23 January 2003) available at https://www.echr.coe.int/Documents/Speech_20070119_Wildhaber_JY_ENG.pdf accessed 28-12-20.

${ }^{104} R$ v Horncastle [2009] UKSC 14, 11 per Lord Phillips.

105 Al-Khawaja and Tahery v UK (Application Nos. 26766/05 and 22228/06) Judgment (Grand Chamber) 15 December 2011, 151; Horncastle v UK (Application No. 4184/10) Judgment 16 December 2014.

106 The cases are (in chronological order): London Borough of Harrow v Qazi [2003] UKHL 43, Connors v UK (Application No. 66746/01) Judgment 27 May 2004; Kay and others $v$ London Borough of Lambeth and others [2006] UKHL 10, Doherty v Birmingham City Council [2008] UKHL 57, Kay v UK (Application No. 37341/06) Judgment 21 September 2010, and Manchester City Council v Pinnock [2010] UKSC 45.

107 'Even before the [ECtHR decision in Kay $v$ UK] we would, in any event, have been of the opinion that this Court should now accept and apply the minority view of the House of Lords in those cases. In the light of Kay, that is clearly the right conclusion. Therefore, if our law is to be compatible with article 8 , where a court is asked to make an order for possession of a person's home at the suit of a local authority, the court must have the power to assess the proportionality of making the order, and, in making that assessment, to resolve any relevant dispute of fact'. Pinnock [49] per Lord Neuberger

108 On the 'forms' of dialogue between the ECtHR and the UK domestic courts, see Merris Amos, 'The Dialogue between United Kingdom Courts and the European Court of Human Rights' (2012) 61 International and Comparative Law Quarterly 557.

${ }^{109}$ Animal Defenders UKSC Animal Defenders International v UK (Application No ) Judgment

${ }^{110} \mathrm{~A}$ and others $\mathrm{n} ; A v U K$ (Application No ) Judgment
} 
cases indicate a willingness on the part of the ECtHR to examine the effectiveness of the domestic law, including its interpretation and application by domestic courts, in securing the ECHR rights; perhaps heralding a shift from a violations approach to human rights adjudication by the ECtHR which is augmented by Additional Protocol No. 16 that affords states parties the opportunity to ask the ECtHR for an advisory opinion on 'questions of principle relating to the interpretation or application of the rights and freedoms defined in the Convention or the Protocols thereto'. ${ }^{111}$ The discernible turn to examining the effectiveness of domestic law in securing the ECHR rights, brings to mind the 'constructive dialogue' model employed by the various treaty bodies, such as the HRC, to supervise compliance with the UN human rights treaties which, by requiring states parties to report on the measures taken to fulfil their international legal obligations, 'contrast to the tradition in international law'112 whereby, as noted above, domestic law evidences a violation. Perhaps in a comparable manner, the institution of a 'constructive dialogue' ${ }^{113}$ between the ECtHR and domestic courts (spurred in large part by the UK within the broader context of a re-affirmation of the principle of subsidiarity) - places domestic law within the interpretative and adjudicatory functions of the ECtHR, inviting consideration of the effectiveness of the domestic courts in securing ECHR rights. ${ }^{114}$

In short, the ECtHR has assured the place of domestic law within the ECHR system (through devices such as the margin of appreciation, living instrument doctrine and the advent of constructive dialogue with domestic courts) while ensuring that the ECHR has effect within the domestic legal systems of states parties, including that of the UK, by way of exercising its adjudicatory and interpretative functions; a duality that is perhaps emblematic of the tension between the 'form' of the ECHR as an international treaty and the 'substance' of the ECHR as a treaty for the 'effective protection of human rights'. ${ }^{115}$ While the ECHR does not have direct effect within the domestic legal system of the UK, the judgments of the ECtHR are binding on

\footnotetext{
111 Additional Protocol No. 16. The UK has not ratified this Protocol, while France and XX which are states parties, have requested an advisory opinion from the ECtHR.

112 Megret n 148

${ }^{113}$ Pinnock [49] per Lord Neuberger. Robert Spano characterises this shift as a 'qualitative, democracy-enhancing approach' to human rights adjudication. See Robert Spano, 'Universality or Diversity of Human Rights? Strasbourg in the Age of Subsidiarity’ (2014) 14 Human Rights Law Review 487, 499.

${ }^{114}$ In this context, Spano has observed the increased emphasis on the exhaustion of domestic remedies, including the availability of such a remedy, as key to the development of an 'age of subsidiarity' by the ECtHR. Robert Spano, n 499..

${ }^{115}$ Belgian Linguistic Case $\mathrm{n}$
} 
the UK where it is a party to the proceedings, ${ }^{116}$ and have exerted 'a persuasive and pervasive influence on judicial decision-making' in the UK, including notably post-HRA, the 'development of the common law'. ${ }^{117}$ With these observations in mind, the next part turns to the place of the ECHR as a human rights treaty in the domestic legal system of the UK.

\section{The HRA: Human Rights Brought Home}

When the UK ratified the ECHR in 1951, it did not become part of domestic law for, as noted above, the principle of sovereign equality dictates that it is for domestic law to determine whether and, if so, how international law is received in the domestic legal order. ${ }^{118}$ As a parliamentary democracy whereby parliament is supreme and treaty making is reserved to the executive 'quite simply, a treaty is not part of English law unless and until it has been incorporated into the law by legislation'. ${ }^{119}$ With the enactment of the HRA, key provisions of the ECHR were brought into domestic law to the extent provided for by the HRA. Thus, in order to understand the place of the ECHR within the domestic legal system of the UK and hence the interplay between the ECHR and the HRA as human rights laws protecting human rights in the UK, it is necessary first, to identify the provisions of the ECHR that have become part of domestic law by virtue of the HRA and second, to determine the extent to which the HRA provides for their implementation. As ever, this is undertaken by reference to the anatomy of human rights laws - rights, obligations and remedies - and from the perspective of international law; all with an eye to the protection afforded to human rights under the HRA.

It is axiomatic to observe that the HRA as '[a]n Act to give further effect to the rights and freedoms guaranteed under the European Convention on Human Rights ${ }^{120}$ protects the civil and political rights enumerated in the ECHR. Indeed, section 1 of the HRA lists Articles 2 12 and 14 of the ECHR along with Articles $1-3$ of Additional Protocol No 1 and Article 1 of Additional Protocol No 13, as the 'Convention rights' protected by the HRA. However, it is evident that not all the ECHR rights are protected by the HRA; notable for its absence is Article

\footnotetext{
${ }^{116}$ Amos, 'The Value of the European Court' $\mathrm{n}$ where she observes that the changes wrought by judgments of the ECtHR are perhaps not as far-reaching as assumed at first glance.

${ }^{117} R$ v Lyons [2002] UKHL 44, [13] per Lord Bingham.

118 As regards the latter Tomuschat observes that '[i]n most countries where human rights treaties have been introduced into the national legal order, they have been given the rank fordinary statutes' Tomuschat $\mathrm{n} 122$.

${ }^{119}$ International Tin per Lord Oliver [694]. The case law is replete with restatements of this foundational premise of the relationship between domestic law and international law as a necessary corollary of parliamentary sovereignty (see, for example, $R v$ Lyons n [13] per Lord Bingham). That said for a forceful rebuke to attempts to bring in the ECHR 'by the back door' see ex parte Brind [718] per Lord Donaldson

${ }^{120}$ HRA, short title.
} 
13 of the ECHR which guarantees the right to an effective domestic remedy. ${ }^{121}$ Suffice to observe at this juncture, that the UK government saw the HRA itself - insofar as it provides for a role for the courts in the adjudication of the Convention rights - as providing for a domestic remedy as per Article 13. ${ }^{122}$ Moreover, the articles listed in section 1 are faithfully reproduced in Schedule 1 of the HRA which, as an annex to the HRA, not only brings the designated ECHR rights (here referred to as Convention rights) directly into domestic law, but also ensures that the Convention rights, as treaty provisions, are an integral part of the HRA.

As such, from the perspective of international law, there is a distinction to be made between the interpretation of the HRA as the 'transformative legislation' and the interpretation of the Convention rights which, as rights under the ECHR, are to be interpreted according to the rules on treaty interpretation as codified in the $\mathrm{VCLT}^{123}$ and with due regard to the decisions of relevant courts on interpretation. ${ }^{124}$ As to the former, when a treaty is transformed into domestic law 'the courts give effect to the domestic legislation, not to the terms of the treaty'. ${ }^{125}$ Thus, although the ECtHR may rule on the interpretation of the Convention rights, 'their rulings are not binding, ${ }^{126}$ and, moreover, as a domestic statute - albeit one transforming international law - it prevails over the pertinent treaty, thereby ensuring the supremacy of Parliament. ${ }^{127}$ When seen in this light, the injunction in section 2 of the HRA for courts 'to take into account' jurisprudence of the ECtHR 'where relevant', appears to be little more than a legislative re-statement of the standard approach of domestic law - or more accurately of the domestic courts - to the interpretation of domestic statutes that implement international law;

\footnotetext{
${ }^{121}$ Also absent from Schedule 1 are Article 1 of the ECHR which as providing the ratione persone, ratione loci and ratione termporis of the ECHR, is unsurprising. However, it did not prevent the UK House of Lords from applying it to distil the ratione loci of the Human Rights Act in Al-Skeini and Others $v$ Secretary of State for Defence [2007] UKHL 26. Similarly the absence of Article 15 of the ECHR pertaining to the ability of states parties to derogate from the ECHR, from Schedule 1 of the HRA did not prevent the UK House of Lords from examining the derogation made by the Government in respect of the measures introduced by Anti-Terrorism, Crime and Security Act 2001 in the Belmarsh Detainee Case n .; perhaps indicating a more nuanced approach of the domestic courts to international law.

122 Rights Brought Home: The Human Rights Bill (Cmd 37882) (TSO 1997) para 1.19.

${ }^{123}$ Fothergill v Monarch Airlines Ltd [1981] AC 251

${ }^{124} R$ v Immigration Appeal Tribunal, ex parte Shah [1999] 2 AC 629

125 Thomas v Bapiste [2000] 2 AC 1 (Privy Council) [23] per Lord Millet.

${ }^{126}$ James Crawford, Brownlie's Principles of Public International Law ( $9^{\text {th }}$ ed OUP 2019061 . See $R v$ Lyons $\mathrm{n}$ [13] per Lord Bingham and [29] per Lord Hoffmann

127 This produces the possibility of a subsequent statute amending or even repealing the transformative statute. Moreover, in the event of a conflict between a subsequent statute and the transforming statute, the presumption that Parliament did not intend to legislate contrary to international obligations applies and may be of use in resolving the conflict.
} 
an observation which is bolstered by the sources doctrine in international law, whereby the ECHR is the source of international law; not the jurisprudence of the ECtHR. ${ }^{128}$

As a final remark on the Convention rights guaranteed by the HRA, it is pertinent to recall that these entail substantive obligations of a negative and positive character. Thus, public authorities which are prohibited from acting in a 'way which is incompatible with a Convention right' under section 6 (1) of the HRA, are enjoined to discharge these obligations. As to who or what are public authorities for the purposes of the HRA, section 6 (3) of the HRA provides that courts are public authorities but explicitly excludes 'either House of Parliament or a person exercising functions in connection to proceedings in Parliament'. While in line with parliamentary sovereignty, this is at odds with the obligation under Article 1 of the ECHR and indeed, under Article 2 (1) of the ICCPR, whereby 'national authorities' include all branches of government - executive, legislative and judicial. Moreover, the ECtHR and the HRC have made it clear that 'public or governmental authorities, at whatever level - national, regional or local - are in a position to engage the responsibility of the State Party'. ${ }^{129}$ By prohibiting public authorities - which include 'local government, the police, immigration officers, prisons' from acting in a manner incompatible with Convention rights, the HRA gives effect to this aspect of the Article 1 obligation to 'secure' the ECHR rights. However, by excluding the executive and Parliament, the HRA produces the curious - although not unknown - result whereby a state party to an international treaty, such as the ECHR, may act lawfully within the domestic sphere but breach its international legal obligations.

As Tomuschat observes civil and political rights are particularly amenable, if not 'designed to be directly invoked by individuals who feel that they have become victims of unlawful government interference'. ${ }^{131}$ By bringing the Convention rights into domestic law, the HRA produces the 'intended legal effect' of civil and political rights by providing for an individual who is a 'victim of an unlawful act' to claim the Convention rights before domestic courts, ${ }^{132}$ who are empowered to determine whether a public authority has acted incompatibility with a Convention right. There are two comments to make here in this respect. Firstly, that an

\footnotetext{
${ }^{128}$ ICJ Statute, Article 36 (1)

${ }^{129}$ HRC, General Comment No. $31 \mathrm{n}$ [4].'The Convention does not merely oblige the higher authorities of the Contracting States to respect for their own part the rights and freedoms it embodies . . . the Convention also has the consequence that, in order to secure the enjoyment of those rights and freedoms, those authorities must prevent or remedy any breach at subordinate levels' Ireland $v U K \mathrm{n}$ [239]

${ }^{130}$ Rights Brought Home: The Human Rights Bill n [2.2]

131 Tomuschat $\mathrm{n} 110$.

${ }^{132}$ HRA section 7
} 
individual must be a 'victim' ${ }^{133}$ is intended 'to bring rights home', ${ }^{134}$ by enabling an individual who is a 'victim of a breach of the Convention standards by the State . . to bring . . [a] . . . case . . . in the British courts'. ${ }^{135}$ In this way the HRA may be said to 'mirror' the ECHR; ${ }^{136}$ however, section 7 of the HRA does not map exactly onto Article 34 of the ECHR insofar as a public authority for the purposes of the former does not include the executive or Parliament which are included as part of the 'national authorities' for the purposes of bringing an individual application before the ECtHR.

The second point of note, is that while courts may determine whether (or not) a public authority has acted in a manner incompatible with a Convention right, section 6 (2) of the HRA provides that a public authority does not act unlawfully when primary legislation demands that the public authority 'could not have acted differently'. A pertinent example is section 3 of the Representation of the People Act 1983 which excludes prisoners from voting. As primary legislation, election officials may not register prisoners to vote and thus, while acting in a manner incompatible with the right to vote - a protected Convention right under the HRA they do not act unlawfully. ${ }^{137}$ In this way, the supremacy of Parliament is upheld as well as the distinction between domestic law and international law, where the former prevails in the event of a conflict. It is notable, however, that while lawful for public authorities to act incompatibility with the right to vote for the purposes of the HRA; this may not be the case in respect of the ECHR. ${ }^{138}$

In a further nod to parliamentary sovereignty and the primacy of domestic law within the domestic legal system, section 3 (1) of the HRA enjoins courts to interpret legislation in a manner compatible with Convention rights 'so far as it is possible to do so'. At first glance, this accords with the general (rebuttable) presumption that as 'Parliament does not intend to act in breach of international law, including therein specific treaty obligations', ${ }^{139}$ legislation

\footnotetext{
${ }^{133}$ HRA section 7 (7).

${ }^{134}$ Rights Brought Home: The Human Rights Bill n [1.19].

${ }^{135}$ Ibid [1.16].

${ }^{136}$ Merris Amos, 'The Dialogue between United Kingdom Courts and the European Court of Human Rights' (2012) 61 International and Comparative Law Quarterly 557, 562

${ }^{137}$ See $R$ (on the application of Pearson) $v$ Secretary of State for the Home Department [2001] EWHC Admin 239 where the High Court found no violation of the right to vote. Also note $R$ (on the application of Chester) $v$ Secretary of State for Justice [2013] UKSC 63. Here, Lady Hale noted: 'In this case, there can be no question of Mr Chester having a cause of action under section 6(1) of the Human Rights Act . . . the public authority could not have acted differently, because of the provisions of the Representation of the People Act, and so by virtue of section 6(2)(a) the act was not unlawful.' Chester [101]. .

${ }^{138}$ See Hirst (No) v UK (Application No ) Judgment

${ }^{139}$ Salomon v Commissioners of Custom and Excise [1968] 2 QB 116 [143] per Lord Diplock.
} 
is to be interpreted in a manner compatible with international law where an ambiguity arises. ${ }^{140}$ However, the government was clear that the interpretative obligation under section 3 (1):

goes far beyond the present rule which enables the courts to take the Convention into account in resolving any ambiguity in a legislative provision. The courts will be required to interpret legislation so as to uphold the Convention rights unless the legislation itself is so clearly incompatible with the Convention that it is impossible to do so. ${ }^{141}$

While the line between what is possible and not may be clear in cases such as the Representation of the People Act; ${ }^{142}$ is not always as distinct as evidenced in the early case law under the HRA which is replete with examples of (im)possibility. ${ }^{143}$ The courts have mapped the contours of the interpretative obligation under section 3 (1) whereby interpretation of legislation must 'go with the grain' (i.e. Parliamentary intention) and meet with the institutional and constitutional competence of the courts (i.e. separation of powers) ${ }^{144}$ thereby reinforcing parliamentary sovereignty and the primacy of domestic law. In doing so, the courts have arguably reverted to a position more aligned with the usual (rebuttable) presumption to interpret legislation in a manner compatible with Convention rights, albeit without the need for ambiguity.

If a higher court, when adjudicating on human rights under the HRA - whether in respect of an act by a public authority or in relation to interpretation of legislation - determines the

\footnotetext{
${ }^{140}$ It is clear that this presumption only applies as an aid to interpretation in instances of ambiguity. This aligns with parliamentary sovereignty whereby if the terms are clear and unambiguous, the duty of the court is to give effect to the domestic law over international law. Thereby, again, raising the possibility that the UK breaches international law. On this point and in the context of the ECHR see $R v$ Lyons $\mathrm{n}$ and $R v$ Secretary of State for the Home Department, ex parte Brind [1991] 1 AC 696

${ }^{141}$ Rights Brought Home: The Human Rights Bill n [2.7]

${ }^{142}$ Nor is there any question of our reading and giving effect to the Act in a way which is compatible with the Convention rights, in accordance with our duty under section 3(1). No-one has suggested that it would be possible to do so in a case such as this. It is obvious that any incompatibility can only be cured by legislation and the courts cannot legislate' Chester n [101] per Lady Hale

${ }^{143}$ See for example In R A (Sexual) and Danny Nicol and Conor Gearty on possibility.

144 The House of Lords set out this approach in Ghadian v Godin-Mendoza [2004] UKHL 30 where Lord Nicholls [33] stated: Parliament, however, cannot have intended that in the discharge of this extended interpretative function the courts should adopt a meaning inconsistent with a fundamental feature of legislation. That would be to cross the constitutional boundary section 3 seeks to demarcate and preserve. Parliament has retained the right to enact legislation in terms which are not Convention compliant. The meaning imported by application of section 3 must be compatible with the underlying thrust of the legislation being construed. Words implied must, in the phrase of my noble and learned friend Lord Rodger of Earlsferry, 'go with the grain of the legislation'. Nor can Parliament have intended that section 3 should require courts to make decisions for which they are not equipped. There may be several ways of making a provision Convention-compliant, and the choice may involve issues calling for legislative deliberation.' On the 'deference trap' set by such an interpretation of section 3 (1) see Alison Young, Ghadian v Godin-Mendoza: Avoiding the deference trap (2005) Public Law 23
} 
existence of an incompatibility with the Convention rights protected under the HRA, it may then issue a declaration of incompatibility. Indeed, in 2007 a declaration of incompatibility was issued by the domestic courts in respect of section 3 of the Representation of the People Act $1983 ;{ }^{145}$ thereby putting the government on notice of the incompatibility. While pursuant to section 4 (6) of the HRA, the incompatible legislation remains valid and in force, the government is entitled to remedy the incompatibility via a remedial order (section 10 of the HRA); which, as alerted to above, the government declined to do so. Thus, when the compatibility of section 3 of the Representation of the People Act with the Convention right to vote was raised again in 2011, the Supreme Court declined to issue a declaration of incompatibility; notwithstanding, the determination that an incompatibility existed and the unavailability of section 3 (1) of the HRA to remedy the legislative incompatibility. ${ }^{146}$

The ECtHR and the HRC have expressed doubts as to whether the HRA, in bringing rights home,${ }^{147}$ produces the 'intended legal effect' of civil and political rights by affording an effective domestic remedy. ${ }^{148}$ Yes, in principle the combined effect of sections 7, 3 and 4 of the HRA enable domestic courts to determine an allegation of incompatibility with the Convention rights (section 7) and, through the interplay of sections 3 and $4,{ }^{149}$ to provide redress. However, as is evident above, the adjudication of human rights by the domestic courts is tempered by considerations of parliamentary sovereignty - both in law and in practice. This is turn indicates the extent to which the HRA gives effect to the ECHR and ultimately, the degree of human rights protection offered thereunder. Thus, while the HRA accords in large measure to the standard position of the domestic courts to transforming legislation, the provisions (e.g the exclusion of the government from the purview of section 6 of the HRA) and their operation (e.g. the Supreme Court declining to issue a declaration of incompatibility), underscores the significance of the ECHR for the protection of human rights in the UK.

The adjudication of human rights by the domestic courts is also tempered by the interpretation given to the section 2 injunction to 'take into account' the jurisprudence of the ECtHR. It was noted above that this provision is closely aligned to the stance of domestic courts to the

\footnotetext{
145 Smith v Scott [2007] SC 345.

${ }^{146}$ Lord Mance referred to the existing declaration of incompatibility along with the relevant judgments of the ECtHR and concluded: 'There is in these circumstances no point in making any further declaration of incompatibility. Chester $\mathrm{n}$ [39] per Lord Mance.

${ }^{147}$ Notwithstanding inferences by the UK to the effect that the HRA gives effect to the ICCPR rights, the HRC was clear that the HRA may only indirectly 'respect and ensure' the ICCPR.

${ }^{148}$ Burden v UK (Application No ) Judgment 'Big Brother Watch v UK (Application No ) Judgment ; HRC, Concluding Observations

${ }^{149}$ See Tom Hickman Francesca Klug
} 
interpretation of treaty provisions brought into domestic law via statute; whereby courts are entreated to interpret the provisions in light of the VCLT rules on treaty interpretation and with due regard to decisions of relevant courts which, due to parliamentary sovereignty and the primacy of the transforming legislation, are not binding on the domestic courts. This was neatly encapsulated by Lord Hoffmann in $R$ (Alconbury Developments Ltd) in the following terms:

The House is not bound by the decisions of the European court and, if I thought that the Divisional Court was right to hold that they compelled a conclusion fundamentally at odds with the distribution of powers under the British constitution, I would have considerable doubt as to whether they should be followed. ${ }^{150}$

While subsequent judgments are peppered with similar references to the non-binding status of the jurisprudence of the ECtHR, the fullest statement of the requirements of section 2(1) of the HRA was provided by Lord Bingham in ex parte Ullah. Here, whilst acknowledging that ECtHR 'case law is not strictly binding', Lord Bingham stated that absent 'special circumstances' domestic courts should follow 'clear and constant' jurisprudence of the ECtHR. ${ }^{151}$ The application of the Ullah principle has resulted in a 'follow as if bound' approach to the jurisprudence of the ECtHR, raising the prospect that international law - or more accurately the interpretation of treaty provisions by an international court - prevails over domestic law, including the transforming legislation; at least insofar as the determination of incompatibility is concerned.

In sum, the place of the ECHR within the domestic legal system of the UK is determined by the HRA which brings the Convention rights and, by way of reference, Article 34, into domestic law; all other ECHR provisions, notably those relating to 'a system for the collective enforcement ${ }^{152}$ of human rights, i.e. the ECtHR remain outside the domestic legal system of the UK. That said, the jurisprudence of the ECtHR in respect of the interpretation of the Convention rights and on standing to bring an individual application, is relevant, although not determinative; for, as a matter of international law, the extent to which the HRA gives effect

\footnotetext{
${ }^{150} R$ (Alconbury Developments Ltd and others) v Secretary of State for the Environment, Transport and the Regions [2001] UKHL 23, [76] per Lord Hoffmann

${ }^{151}$ Ullah n [20] per Lord Bingham. Arguably Lord Slynn is the author of the principle when he stated: 'In the absence of special circumstances it seems to me that the court should follow any clear and constant jurisprudence of the European Court of Human Rights. If it does not do so there is a least a possibility that the case will go to that court which is likely in the ordinary case to follow its own constant jurisprudence'. $R$ (Alconbury Developments Ltd) n [26] per Lord Slynn.

152 ECHR, Preamble.
} 
to the Convention rights and enables an individual to claim those rights before a domestic court is determined by the provisions of the HRA. Here, it was noted that section 6 of the HRA reflects, albeit imperfectly, the range of national authorities captured by the Article 1 obligation 'to secure' the ECHR rights; while sections 7, 3 and 4 of the HRA give indirect effect to the Article 13 obligation to provide an effective domestic remedy. The concerns as the effectiveness of the HRA in providing a remedy, along with the fact that government is not a public authority for the purposes of the HRA underscore the continued importance of the ECtHR for the protection of human rights in the UK and draws attention to the above observations regarding the impact of the ECHR, as an international treaty, within the domestic legal system of the UK.

\section{Interpreting the Convention Rights: the role of the jurisprudence of the ECtHR}

As a human rights law, the HRA protects Convention rights, prohibits public authorities including the courts - from acting in a manner incompatible with Convention rights and enables the domestic courts to determine an allegation of incompatibility with a Convention right and, if appropriate, to remedy such incompatibility. It is in this latter respect that the HRA may be said to implement the Article 13 obligation to provide an effective domestic remedy; while, more generally the HRA may be said to implement the Article 1 obligation 'to secure' the ECHR rights, although in a qualified manner. As a domestic statute the HRA, albeit one that 'gives further effect' to the ECHR, bears the footprint of parliamentary sovereignty and is largely reflective of the typical stance of domestic law, or more precisely of the domestic courts, towards international law. In doing so the dualist position of the domestic legal system is confirmed, minimising the impact of the ECHR as an international treaty. Yet, section 2 of the HRA enjoins courts to 'take into account' the jurisprudence of the ECtHR 'where relevant' and thus attention is drawn to the status and use of such jurisprudence in domestic judicial decision-making under the HRA. It is against this backdrop, that this section - somewhat cursorily - explores the interpretation of section 2 in order to identify the status and use of the jurisprudence of the ECtHR within the domestic legal system.

The Ullah principle, whereby domestic courts follow 'clear and constant' jurisprudence of the ECtHR absent 'special circumstances' remains the authority on the interpretation of section 2 (1) of the HRA. ${ }^{153}$ As such, it sets the parameters of the extent to which the Convention rights

\footnotetext{
${ }^{153}$ See for example $R$ (Al-Skeini and others) v Secretary of State for Defence [2007] UKHL 26 [90] per Baroness Hale and [105] per Lord Brown and Ambrose v Harris [2011] UKSC 43 [17-20] per Lord Hope; but see [126 $130]$ per Lord Kerr. This is not notwithstanding calls for the Supreme Court to revisit the principle (see $R$ (on the application of the Children's Rights Alliance for England) v Secretary of State for Justice [2013] EWCA Civ 34
} 
are given effect in the domestic legal system of the UK, specifically the content, scope and application of the Convention rights. In brief, the Ullah principle determines the status of the jurisprudence of the ECtHR within domestic judicial decision-making as persuasive and authoritative, although not 'strictly binding', operating in a similar way to judgments of the House of Lords/Supreme Court, ${ }^{154}$ the use of which varies according to the existence (or otherwise) of a 'clear and constant' line of jurisprudence and/or the existence of 'special circumstances'. In other words, the Ullah principle is a rebuttable presumption to follow the jurisprudence of the ECtHR. The adherence of the higher courts to this principle ${ }^{155}$ has not only produced some lively interchanges between their Lordships; but also perhaps, on occasion, curious outcomes at both a domestic and European level.

For example, following the ECtHR judgment in A and others $v U K,{ }^{156}$ Lord Rodger - in an epitome of pithy one-liners - declared that he would allow the appeal as 'Argentoratum locutum, iudicium finitum - Strasbourg has spoken, the case is closed'. ${ }^{157}$ In a comparable manner, the House of Lords has followed the judgments of the ECtHR, for example in Bellinger $v$ Bellinger in respect of Goodwin (discussed above), resulting a declaration of incompatibility; similarly the Supreme Court followed the ECtHR judgment in Hirst (No. 2) $v U K$ in $R v$ Chester, although, as noted above, it declined to issue a declaration of incompatibility. It is perhaps notable that these examples relate to judgments of the ECtHR where the UK is a party to the proceedings. As observed above, such judgments are binding on the UK as a matter of international law and thus the UK - whether the executive, legislature or judiciary as national authorities - is bound to implement them. ${ }^{158}$ In contrast, in the Animal Defenders Case, the

[64] per Laws LJ) or the slow but discernible chipping away of the principle by the expansion of 'special circumstances' (see Roger Masterman, The Mirror Crack'd, UK Constitutional Law Blog 13 February 2013 available at https://ukconstitutionallaw.org/2013/02/13/roger-masterman-the-mirror-crackd/ accessed on 28-1220)

154 As Aileen Kavanagh has observed this means 'that they [the courts] are not obliged to follow Strasbourg case law in every case. In other words, the binding nature of those precedents is partial rather than absolute, and the courts retain the discretion to depart from Strasbourg jurisprudence 'in special circumstances'. In effect, the courts operate a strong presumption in favour of following Strasbourg case law in the normal case, which can only be rebutted in exceptional cases' ... [as so interpreted by the House of Lords] section 2 gives the Strasbourg case law the same status or precedential weight as its own precedents'. Aileen Kavanagh, Constitutional Review under the UK Human Rights Act (CUP 2009) 148 (emphasis in original).

155 The House of Lords confirmed in Pinnock that when faced with conflicting judgments from the ECtHR and the House of Lords, lower courts are to follow the House of Lords.

${ }^{156} A$ and others $v$ UK (Application No. 3455/05) Judgment (Grand Chamber) 19 February 2009. The application dealt with substantially the same matter that was at issue before the House of Lords in Secretary of State for the Home Department v AF (FC) [2009] UKHL 28.

${ }^{157} A F(F C) \mathrm{n}$ [98] per Lord Rodger. Lord Scott similarly allowed the appeal but noted that the common law would have produced the same result. See $A F(F C)$ [96]

${ }^{158}$ Lord Mance makes a comparable point when stating: ' $[\mathrm{I}] \mathrm{t}$ is our duty to give effect to the domestically enacted Convention rights, while taking account of Strasbourg jurisprudence, although caution is particularly apposite 
House of Lords did not follow the substantial and sophisticated jurisprudence of the ECtHR on freedom of expression (Article 10 of the ECHR), especially as regards the limitation clause which was addressed, on point, in VgT Verein gegen Tierfabriken $v$ Switzerland. ${ }^{159}$ Here, the House of Lords conducted a careful and in-depth analysis of the relevant jurisprudence, alongside the passage of the Communications Act 2003, ${ }^{160}$ to conclude that the government had struck an appropriate balance between freedom of expression and 'the rights of others' and thus the legislation was not incompatible with the Convention right of freedom of expression. Unsurprisingly the case went to the ECtHR where, to the surprise of many an academic, the ECtHR agreed with the House of Lords, albeit by a very narrow margin, and found no violation of Article 10 and in doing so attached 'considerable weight' to the reviews undertaken by both Parliament and the House of Lords. ${ }^{161}$ Indeed, Spano observes that it was the careful analysis of the government's position and relevant ECtHR jurisprudence by the House of Lords that distinguishes the Animal Defenders Case from Hirst (No.2) where the UK was found to have breached Article 3 of Additional Protocol No. 1. ${ }^{162}$

That said, the House of Lords conducted a comparable exacting analysis of the balance struck by the relevant legislation in Kay $v$ Lambeth; which, as noted above, did not survive scrutiny by the ECtHR, prompting the House of Lords to 'follow' the judgment in Pinnock, although with the caveat that 'we would, in any event, have been of the opinion that this Court should now accept and apply the minority view of the House of Lords' expressed in the previous domestic cases. ${ }^{163}$ This decision is instructive in terms of what constitutes 'special circumstances' permitting the domestic courts to depart (as opposed to distinguish as per the Animal Defenders Case) from 'clear and constant' jurisprudence of the ECtHR. Here, in echoes of Lord Hoffmann cited above, Lord Neuberger stated:

Where, however, there is a clear and constant line of decisions whose effect
is not inconsistent with some fundamental substantive or procedural aspect
of our law, and whose reasoning does not appear to overlook or

where Strasbourg has decided a case directly in point or, perhaps, where there are mixed messages in the existing Strasbourg case law and, as a result, a real judicial choice to be made there about the scope or application of the Convention'. R (Smith) v Oxfordshire Assistant Deputy Coroner [2010] UKSC 26 [199] per Lord Mance.

${ }^{159}$ VgT Verein gegen Tierfabriken $v$ Switzerland (Application No ) Judgment

${ }^{160}$ For example, Lord Bingham observed: 'In enacting the 2003 Act, Parliament paid close attention to the important decision of the European Court of Human Rights in VgT Verein gegen Tierfabriken v Switzerland' Animal Defenders International n [7] per Lord Bingham.

${ }^{161}$ Animal Defenders International v UK (Application No 48876/08) Judgment 22 April 2013 [116].

162 Spano n 498.

${ }^{163}$ Pinnock n [48] per Lord Neuberger. Similar to the caveat entered by Lord Scott in AF (No. 3) although here, in respect of the common law. 
misunderstand some argument or point of principle, we consider that it would be wrong for this Court not to follow that line. ${ }^{164}$

It was this belief - that 'the relevant case law of the ECtHR is wrong' 165 - that prompted Lord Phillips to extend an invitation to the ECtHR to re-consider its jurisprudence in $R v$ Horncastle.

The second circumstance in which the domestic courts may not follow clear and constant jurisprudence of the ECtHR under the Ullah principle is when the margin of appreciation applies. By way of illustration, the House of Lords was faced with a discretion to act, due to the likely application of the margin of appreciation, in In Re P. ${ }^{166}$ while the Supreme Court grappled with a similar situation in Ambrose $v$ Harris where there was no clear and constant jurisprudence to follow. ${ }^{167}$ In the former, the House of Lords was exercised by the question who exercises the discretion - or perhaps, more aptly, who secures the Convention rights with the choice falling between the courts and Parliament which, as succinctly observed by Lady Hale, involves an assessment of the role of domestic courts under the HRA, specifically:

[w] hat did Parliament mean when it required the courts to act compatibly with the Convention rights? Did it mean us only to go as far as Strasbourg would go? Or did it mean us, in at least some cases, to be able to go further?

Here, the House of Lords answered in the affirmative; while Lord Hope, when faced with a comparable freedom (albeit in the absence of jurisprudence from the ECtHR) in Ambrose $v$ Harris cautioned against 'expand[ing] the scope of the Convention right further than the jurisprudence of the Strasbourg court justifies'. ${ }^{168}$ While Lord Dyson was somewhat sympathetic to the proposition to moving beyond the jurisprudence of the ECtHR where, as in the instant case 'there is no clear and constant line of authority'; ${ }^{169}$ it was Lord Kerr who mounted a plea to up-end 'Ullah-type reticence' and 'anticipate developments at the supra national level of the Strasbourg court ... and ... go where Strasbourg has not yet gone' ${ }^{170}$

\footnotetext{
164 Ibid.

165 Merris Amos, 'Transplanting Human Rights Norms: The case of the United Kingdom's Human Rights Act' (2013) 35 Human Rights Quarterly 386, 390.

${ }^{166}$ In R P [2008] UKHL 38.

${ }^{167}$ Ambrose v Harris [2011] UKSC 43

${ }^{168}$ Ibid [20] per Lord Hope.

${ }^{169}$ Ibid [102] per Lord Dyson.

${ }^{170}$ Ibid [126] per Lord Kerr. See also Kerr, 'The UK Supreme Court: The modest under-worker of Strasbourg?' Clifford Chance Lecture (25 January 2012) available via https://www.supremecourt.uk/news/speeches.html accessed 28-12-20.
} 
As indicated in the introduction, the application of the Ullah principle has prompted concerns - both amongst the judiciary and academia - which, as evident above, are ultimately centred on the ability of the domestic courts to develop a 'municipal' jurisprudence in respect of the Convention rights. ${ }^{171}$ Having canvassed the parameters set by the Ullah principle, it is evident that this interpretation of the injunction in section 2 (1) of the HRA for courts to 'take into account' the jurisprudence of the ECtHR 'where relevant' determines the extent to which the Convention rights are given effect within the domestic legal system of the UK, i.e. the protection afforded under the HRA. Arguably, in light of the comments regarding the stance of the domestic courts to transforming legislation in the context of section 2 , the parameters thus set by Ullah - determining the status and use of the jurisprudence of the ECtHR in domestic judicial decision-making - are not intended by the HRA as the transforming legislation. ${ }^{172}$ Thus, in order to determine whether the status and use of the jurisprudence of the ECtHR is warranted, it is necessary to return to first principles and the reasons offered for following 'clear and constant' jurisprudence absent 'special circumstances'.

\section{Bridging the ECHR and the HRA: Revisiting the Ullah principle}

The interplay between the ECHR and the HRA as human rights laws, when viewed from the perspective of international law, is one of a relationship between international law and domestic law. Notwithstanding the monist aspirations of international law - exemplified by pacta sunt servanda - the ECHR, as an international treaty, and the HRA, as a domestic statute, remain distinct and provide for separate systems of protection for human rights in the UK. That said, by bringing the Convention rights into domestic law, the HRA provides for a point of interaction between the HRA and the ECHR as human rights laws for the protection of human rights in the UK. As currently framed, this interaction is one of convergence (following the ECtHR's interpretation of the Convention rights) or divergence (not following the interpretation of the ECtHR in 'special circumstances'). The aim of this part of the paper is to explore the possibility of a synergy between the ECHR and the HRA, centred on the interpretation of the Convention rights. In order to do so, it is necessary to assess the reasons for the Ullah principle, which, as ever, is undertaken from the perspective of international law.

There are three reasons provided in the domestic case-law for following 'clear and constant' jurisprudence of the ECtHR absent 'special circumstances'; one pragmatic, one based on the

\footnotetext{
${ }^{171}$ See for example Lord Irvine, ‘A British Interpretation of Convention Rights' (2012) Public Law 237.

${ }^{172}$ A similar conclusion was reached by Leigh and Masterman, albeit from the perspective of domestic law. See
} 
HRA, and finally, one premised on the notion that the Convention rights are international rights.

The pull towards the jurisprudence of the ECtHR is one of practical reality whereby if less protection is afforded 'there is at least a possibility that the case will go to that court which is likely in the ordinary case to follow its own constant jurisprudence'. ${ }^{173}$ This accords with the rationale behind introducing the HRA, namely of 'bringing rights home', of making 'more directly accessible the rights which the British people already enjoy under the Convention'; ${ }^{174}$ which was echoed by Lord Kerr in the following terms: 'It is to be expected, indeed it is to be hoped, that not all debates about the extent of Convention rights will be resolved by Strasbourg'. ${ }^{175}$ As suggested by this statement, such a pragmatic approach to the status of the jurisprudence of the ECtHR is warranted as a matter of international law. As observed above states parties to the ECHR bear primary responsibility 'to secure' the ECHR rights and, as such, the ECtHR operates on the principle of subsidiarity whereby, as an international court - albeit for the 'collective enforcement' of human rights - it is a court of last resort. As such, the principle of subsidiarity does not require that the domestic courts 'keep pace' with the jurisprudence of the ECtHR as it remains open for states parties to provide more generous protection of the ECHR rights. While, as Lord Brown observed, more generous protection by domestic courts may produce the curious result whereby a state party may not 'go to Strasbourg to have it corrected'; ${ }^{176}$ a result somewhat addressed by the possibility of Parliament doing so by way of legislation.

The second and third reasons were identified by Lord Bingham when advancing the Ullah principle as follows:

This reflects the fact that the Convention is an international instrument, the correct interpretation of which can be authoritatively expounded only by the Strasbourg court. From this it follows that a national court subject to a duty such as that imposed by section 2 should not without strong reason dilute or weaken the effect of the Strasbourg case law. It is indeed unlawful under section 6 of the 1998 Act for a public authority, including a court, to act in a way which is incompatible with a Convention right. It is of course open to

\footnotetext{
${ }^{173} R$ (Alconbury Developments Ltd) n [26] per Lord Slynn

${ }^{174}$ Rights Brought Home: The Human Rights Bill n [1.19]

${ }^{175}$ Ambrose $\mathrm{n}$ [129] per Lord Kerr.

${ }^{176}$ Al-Skeini n [105] per Lord Brown
} 
member states to provide for rights more generous than those guaranteed by the Convention, but such provision should not be the product of interpretation of the Convention by national courts, since the meaning of the Convention should be uniform throughout the states party to it. The duty of national courts is to keep pace with the Strasbourg jurisprudence as it evolves over time: no more, but certainly no less. ${ }^{177}$

The somewhat pithy observation that as a public authority courts are prohibited from acting in a manner incompatible with Convention rights is shorthand for the 'requirement that the court determine if the Convention right has the effect claimed'; ${ }^{178}$ and not as it may appear at first glance, an injunction not to act in a manner incompatible with the Convention rights as interpreted by the ECtHR. ${ }^{179}$ This requirement is somewhat reflected in the fact that courts are national authorities for the purpose of the ECHR, specifically the Article 1 obligation 'to secure' the ECHR rights.

The pull towards the jurisprudence of the ECtHR is arguably strongest upon reflection that Lord Bingham views the Convention rights as international rights and, as such, are for the ECtHR to interpret. Moreover, as was evident in the preceding part, this forecloses the possibility of developing a more generous protection of the Convention rights by the domestic courts; as a uniform interpretation is required. However, the status of the Convention rights as international rights is by no means assured. Indeed In Re McKerr, which preceded the pronouncement of the Ullah principle by a matter of months, Lord Hoffmann unequivocally stated:

What the Act has done is to create domestic rights expressed in the same terms as those contained in the Convention. But they are domestic rights, not international rights. Their source is the statute, not the Convention. They are available against specific public authorities, not the United Kingdom as a

\footnotetext{
${ }^{177}$ Ex parte Ullah n [20] per Lord Bingham.

${ }^{178}$ Ambrose n [129] per Lord Kerr.

179 "“Convention rights" within the meaning of the 1998 Act are domestic and not international rights. They are applicable in the domestic law of the United Kingdom and it is the duty of the courts to interpret them like any other statute. When section 6(1) says that it is unlawful for a public authority to act incompatibly with Convention rights, that means the domestic rights set out in the Schedule to the Act and reproducing the language of the international Convention'. In Re P n [33] per Lord Hoffmann.
} 
state. And their meaning and application is a matter for domestic courts, not the court in Strasbourg. ${ }^{180}$

The passage of time and the approval of the Ullah principle in later judgments has not diluted the potency of this debate; Lord Hoffmann, ${ }^{181}$ as well as Lord Mance ${ }^{182}$ for example, have maintained the position that the Convention rights are domestic rights, which prompted Lady Hale to ask:

Are the "Convention rights" for the purpose of section 1(1) of the 1998 Act, the rights as defined by Strasbourg but given effect in UK law, or are they the rights defined by United Kingdom law within the parameters defined by Strasbourg? ${ }^{183}$

The domestic case-law does not disclose a definite answer either way which is peppered with not infrequent skirmishes between the Justices on the matter. ${ }^{184}$ Such disagreement may be resolved by reference to the distinction noted in the preceding part, between interpretation of the transforming legislation and the interpretation of the treaty provisions that form an integral part of that legislation. On this view - drawn from the standard account of the place of international law within the domestic legal system of the UK - the Convention rights are international rights which are to be interpreted by the domestic courts as international rights with recourse to the VCLT rules on treaty interpretation and with due regard to relevant decisions of courts, which although persuasive and authoritative, are not determinative. The extent to which the Convention rights - as interpreted by a domestic court - are given effect within the domestic legal system is determined by the HRA as the transforming legislation.

And herein lies the nub of the issue: the Ullah principle, as an interpretation of section 2 (1) of the HRA, denies domestic courts an interpretative function under the HRA ${ }^{185}$ on the twin bases

\footnotetext{
${ }^{180}$ In Re McKerr [2004] UKHL 12 [65] per Lord Hoffmann.

${ }^{181}$ In Re P n [33] per Lord Hoffmann. See also Lord Hoffmann, 'The Universality of Human Rights' Judicial Studies Board Annual Lecture 19 March 2009 available at https://www.judiciary.uk/announcements/speech-bylord-hoffmann-the-universality-of-human-rights/ accessed 28-12-20.

${ }^{182} R$ (Smith) n [199] per Lord Mance. In Re P n [128-129] per Lord Mance.

${ }^{183}$ In Re P n [85] per Lady Hale.

${ }^{184}$ See, for example, the divergent approaches in In Re P, especially as between Lords Hoffmann and Mance on the one hand and Lady Hale on the other; also note Lord Scott's invocation of the Convention rights as domestic rights position in the Animal Defenders Case (Animal Defenders n [44]) incurred a rebuke by Lord Bingham in the following terms: 'I cannot, with regret, concur in all that my noble and learned friend Lord Scoot of Foscote says'. Animal Defenders n [37] per Lord Bingham.

185 'But such provision should not be the product of interpretation of the Convention by national courts.' Ambrose n [17] per Lord Hope
} 
of 'institutional and constitutional' competence ${ }^{186}$ and 'comity' to the ECtHR. ${ }^{187}$ The former is not required from a purposive reading of the HRA - indeed the opposite would appear to be the case as the interpretative obligation of section 3 (1) applies to the HRA - and does not accord with the general stance of the domestic courts towards transforming legislation. While the latter does not preclude an interpretative function on the part of the domestic courts as the ECHR permits states parties to provide for more generous protection via Article 53 of the ECHR and the ECtHR draws on state practice, including that of domestic courts as national authorities, to interpret the ECHR rights 'in light of present-day conditions'. Moreover, as is evident from the preceding part, the domestic courts have shown a marked reluctance to embrace an interpretative role when the Ullah principle permits - as when the margin of appreciation would apply or in the absence of a clear and constant line of jurisprudence from the ECtHR - largely on the basis of competence and the separation of powers. ${ }^{188}$

In sum, when viewed from the vantage point of international law, the parameters set by the Ullah principle - which, in turn, determines the extent to which the Convention rights are given effect to within the domestic legal system - do not necessarily hold up to scrutiny; moreover, it is a position which is problematic as a matter of international law as it treats the jurisprudence of the ECtHR as a source of law; rather than the ECHR which as a human rights law creates obligations for states parties, enumerates the human rights to be protected, and provides for a system of redress. Moreover, it is not immediately apparent from the text of the ECHR that the ECtHR has exclusive competence to interpret the ECHR rights; indeed, such a position would seem contrary to the principle of subsidiarity and undermine the role of state practice in the interpretation of treaties. In short, the international law perspective brought to bear on the HRA as a domestic statute implementing the ECHR, discloses that the domestic courts are not de-barred from interpreting the Convention rights; indeed, the international perspective suggests that domestic courts should be actively developing an interpretative role in the adjudication of human rights under the HRA. Herein lies the potential for a synergy between the ECHR and the HRA as human rights laws guaranteeing human rights in the UK while

\footnotetext{
${ }^{186}$ Ian Leigh and Roger Masterman observe 'that the real objection to United Kingdom courts going beyond the minimum protection that the Convention requires is their fear of being tarred judicial activisits and legislators, rather than respect for the Strasbourg court'. Ian Leigh and Roger Masterman, Making Rights Real: The Human Rights Act in its first decade (Hart 2008) 74- 75.

${ }^{187}$ Merris Amos, 'The Principle of Comity and the Relationship between British Courts and the European Court of Human Rights' in P Eeckhout and T Tridimas (eds) Yearbook of European Law 2009 (OUP 2010)

${ }^{188}$ This is perhaps typified by the questions posed by Lady Hale and noted by Lord Hoffmann as to who decides on rights in $\operatorname{In} \operatorname{Re} P$.
} 
acknowledging that one is an international treaty with monist aspirations and a dualist outlook and the other is a domestic statute with monist tendencies within a dualist system.

\section{Post Script}

This paper was a reflection on the interplay between the ECHR and the HRA as human rights laws protecting human rights in the UK. It told a story of how the ECHR and the HRA operate to protect human rights in the UK from the vantage point of international law with a view to identifying possibilities for enhancing the protection thereunder. The conclusion to which may be neatly summarised by the observation that the effectiveness of international law, including the international law on human rights, depends on its implementation by the states parties. 